\title{
SENS PRZEOBRAŻEŃ MODLITWY ZA ŻYDÓW W RZYMSKIEJ LITURGII WIELKIEGO PIĄTKU
}

Usunięcie przez papieża Jana XXIII z wielkopiątkowej modlitwy powszechnej zwrotów „pro perfidis judaeis” i ,judaica perfidia” przeszło do historii jego pontyfikatu i stało się symbolem przemian w stosunkach między Kościołem a Żydami. Rzadziej może pamięta się, że owo usunięcie określenia perfidia zapoczątkowało dalszą przemianę formuły modlitwy, tak że w aktualnej, czwartej wersji bardzo niewiele pozostało z jej pierwotnego brzmienia. Kolejne etapy tej przemiany nie są pozbawione teologicznego znaczenia i refleksja nad nimi może się przyczynić do jaśniejszego, precyzyjniejszego uchwycenia relacji wiążącej Kościół Chrystusowy z Izraelem, co właśnie spróbuję zasygnalizować na poniższych stronicach.

Od razu warto może jednak zwrócić uwagę na zasadniczy problem, wokół którego obracać się będzie teologiczna analiza zmniejszających się tekstów modlitwy: pojęcie „Żydzi” tak, wydawałoby się, jasno określone, z chrześcijańskiego, teologicznego punktu widzenia wcale takie proste i jednoznaczne nie jest, jak nie jest prosty stosunek Kościoła do określonego nim ludu. Jeśli patrzeć bowiem z perspektywy Bożego Objawienia Starego i Nowego Testamentu, chodzi tu o lud zupełnie szczególny, powołalny do istnienia i ukonstytuowany nadzwyczajnym i niepowtarzalnym działaniem Boga, o lud, w którego prerogatywy i przywileje wchodzi zgromadzenie święte czasów mesjańskich, Ekklesia tou Christou, Kościól Chrystusowy powołany w swej Glowie i pierwocinach swych członków (Maryja!) spośród tego właśnie ludu, by rozszerzyć się na członki pochodzące następnie w przeważającej większości (choć nigdy wyłącznie) spośród narodów pogańskich, podczas gdy przeważająca większość (choć nigdy całość) tego ludu, nie uznając w Jezusie z Nazaretu swego Mesjasza, nie utraciwszy wprawdzie nieodwołanych Bożych obietnic, pozostaje jednak poza Mesjańskim Zgromadzeniem (=Kościołem) jedynego Ludu Bożego, którego korzeń stanowi. Popularne określenie „Żydzi” stosowane najczęściej z myślą o tej części powołanego do istnienia przez Boga ludu Izraela, która aktualnie znajduje się poza Kościołem Chrystusowym, ma jednak na uwadze organiczną ciągłość tego ludu od samych jego początków i choć częściej akcentuje również specyficzną formę religijną i społeczną właściwą dla ogółu nie przyjmującego Jezusa jako Mesjasza (judaizm, Synagoga), to niekiedy obejmuje również Żydów ochrzczonych, raz z myślą o wspólnych nad- 
przyrodzonych początkach, to znów o czysto naturalnie pojętej więzi etnicznej. Intencja i treść modlitwy Kościoła za Żydów będzie w istotny sposób zależeć od tego, w jaką stronę będzie się kierowało jego rozumienie pojęcia „Żydzi”.

\section{Formuła pierwotna}

Wielkopiątkowa modlitwa za Żydów korzeniami sięga starożytności chrześcijańskiej. Wielki Piątek poświęcony wspomnieniu męki i śmierci Pana był wszędzie dniem, w którym nie celebrowano liturgii eucharystycznej. W Rzymie, zanim z Jerozolimy przywędrował (w VII w.?) zwyczaj adoracji krzyża, ceremonie Wielkiego Piątku ograniczały się do czytań biblijnych przeplatanych śpiewami i zwieńczonych modlitwą powszechną, która nie stanowiła wówczas, jak potem przez długie wieki aż do ostatnich reform, liturgicznego wyjątku zarezerwowanego tylko na ten jeden dzień w roku. Podobnie jak to jest znów dziś, wezwania do modlitwy następowały normalnie po czytaniach i obejmowały codzienne potrzeby Kościoła i cały świat. Seria modlitw, która przetrwała w liturgii rzymskiej Wielkiego Piątku, swymi intencjami odpowiada modlitwom powracającym w codziennej liturgii Kościołów Wschodnich. Opuszczenie tych modlitw w późniejszych czasach w codziennej liturgii rzymskiej a zachowanie ich tylko w tym jednym dniu, kiedy nie następowała później liturgia eucharystyczna, sprawiło, że modlitwa za Żydów stała się czymś wyjątkowym, a jej treść czytano przez długie wieki niemal wyłącznie w oświetleniu wydarzeń związanych z Męką Pańską ${ }^{1}$. Tekst Orationes sollemnes, wśród których znajduje się interesująca nas modlitwa za Żydów, został przechowany przez główne sakramentarze stanowiące źródło poznania liturgii łacińskiej: gelazjański i gregoriański; zawiera go także Missale gallicanum vetus ${ }^{2}$. Jest on już dobrze ustalony u progu VII w. Ciąg modlitw, z których każda składa się z wezwania do modlitwy i właściwej oracji, obejmuje kolejno: cały Kościól, papieża, wszystkie stany Kościoła (od biskupów po wdowy), katechumenów, cesarza, wszystkich znajdujących się w niebezpieczeństwie, a następnie „heretyków i schizmatyków”, „perfidnych Żydów” i „pogan”3. Tekst przedostatniej modlitwy, w którym wydania krytyczne źródeł odnotowują tylko drobne i nie-

${ }^{1}$ Por. L. D u ch e s ne, Origines du culte chrétien. Etude sur la liturgie latine avant Charlemagne, Paris 1925, s. 182-183; 247-248; 261-263; Joseph A. J u n g m a n n, Liturgie der christlichen Frühzeit bis auf Gregor den Grossen, Freiburg Schweiz 1967, s. 250-252; Louis B o u y e r, Misterium paschalne, Kraków 1973, s. 198 i przypis 2, s. 351. Por, też antologia tekstów dotyczących liturgii w cytowanym dziele L. D u che sne'a s. $487-488 ; 502-503$.

2 Por. Antoine Ch a vass e, Le Sacramentaire Gélasien (Vaticanus Reginensis 316). Sacramentaire presbytéral en usage dans les titres romains au VIIe siècle, Strasbourg 1958, s. 634.

${ }^{3}$ Por. Jean D e s hus se s, Le Sacramentaire Grégorien. Ses principales formes d'après les plus anciens manuscrits. Edition comparative, t. I, Fribourg 1971, s. 177-180; por. też L. D u ch e s n e, jw., s. 183. 
istotne dla sensu warianty ${ }^{4}$ znalazł się w niezmienionej formie w potrydenckim mszale Piusa V i aż do czasów nam współczesnych brzmiał ${ }^{5}$ :

\section{Oremus et pro perfidis Judaeis:}

ut Deus et Dominus noster auferat velamen de cordibus eorum: ut et ipsi agnoscant Jesum Christum Dominum nostrum.

[Non respondetur „Amen”, nec dicitur „Oremus”, aut „Flectamus

genua”, aut „Levate” sed statim dicitur]

Omnipotens sempiterne Deus, qui etiam judaicam perfidiam a tua misericordia non repellis:

exaudi preces nostras, quas pro illius populi obcaecatione deferimus, ut agnita veritatis tuae luce, quae Christus est, a suis tenebris eruantur.

Per eundem Dominum. Amen.

Wyjaśnijmy najpierw sprawę ujętej w nawias rubryki. Wszystkie pozostałe intencje tej serii modlitw kończyły się wezwaniem celebransa „Oremus”, następnie diakon wzywal wiernych do uklęknięcia i po chwili modlitwy w ciszy na wezwanie subdiakona lud powstawał, by wysłuchać oracji. Ponieważ wyjątkowo wezwanie modlitwy za Żydów kończy się zwrotem ,Jesum Christum Dominum nostrum", dla uniknięcia mechanicznej aklamacji amen, która w tym momencie byłaby nie na miejscu (bo właściwej modlitwy jeszcze nie było), wprowadzono rubrykę ostrzegającą przed takim niebezpieczeństwem. Gorzej, że, nie wiadomo dokładnie jak, w IX w. zawieszono w tym jednym przypadku również wezwanie do uklęknięcia i powstania ${ }^{6}$. To swoiste „prawo wyjątkowe” dawało wybitnym nawet komentatorom tekstu liturgicznego okazję do komentarzy świadczących o tym, jak nieostro widziano prawdziwą relację między Żydami a Kościołem i jak łatwo przychodziło patrzeć na „zaślepienie”, o którym mowa w modlitwie, tylko przez pryzmat epizodów Męki . Ono też pierwsze

${ }^{4}$ Najważniejsze z nich, według wyżej cytowanej edycji J. Deshussesa dotyczą porządku wyrazów: Deus (ac) Dominus i Christum lesum, oraz synonimów: agnoscant/cognoscant, obcaecationel caecatione; - por. tamże s. 179 (aparat krytyczny pod tekstem).

${ }_{5}$ Missale Romanum ex decreto sacrosancti Concilii Tridentini restitutum, s. Pi i V Pontificis Maximi iussu editum, aliorum Pontificum cure recognitum, a Pio X reformatum et Benedicti XV auctoritate vulgatum, Romae-Tornari-Parisiis 1950, s. 178-179. Rozbicie tekstu na poszczególne wiersze pochodzi od autora artykułu.

${ }^{6}$ Por. Jacques Ma rit a in, Questions de consciense, Paris 1938, s. 63 (przypis 1. z powołaniem się na: Erik Pe te r s o n, Perfidia Iudica, „Ephemerides Liturgicae” 1936; - artykuł cytowany również przez Charlesa Jou r n e t a w: Destinées d'Israël, Paris 1945, s. 143 przypis 1).

7 ,Po tym wstępie, Kościół przez usta Diakona już ludu nie wzywa do uklęknięknięcia, jakgdyby dzisiaj lękał się przypominać świętokradzki pokłon Żydów, szyderstwem urągających bólowi Baranka. Lecz od pamięci w modlitwie Oblubienica Chrystusowa nie wyłącza katów Pana, miłosierdziu Jego ich polecając słowy celebransa: (tu następuje tekst oracji)" - Dom Prosper Gu ér a n e r, Rok liturgiczny, t. VI: Tydzień Męki Pańskiej i Wielki Tydzień, przekład St. Świertlickiego i H. Nowackiego, Łomża 1935, s. 529. Jest to cały komentarz do tej modlitwy. Sam tekst praktycznie nie zostaje objaśniony. 
stało się przedmiotem reformy, o czym wspomnimy jeszcze poniżej. Wróćmy jednak do samego tekstu modlitwy.

Jest to modlitwa „pro perfidis Judaeis”. Samo użycie określenia perfidi może być rozumiane dwojako. Można je rozumieć jako deprecjonujący epitet pod adresem wszystkich Żydów — i tak, niestety, bardzo często ją rozumiano, zwłaszcza odkąd określenie perfidi nabrało w potocznym rozumieniu tego nieprecyzyjnego, ale niedwuznacznie pejoratywnego znaczenia, jakie ma w językach nowożytnych słowo perfidia czy perfidny ${ }^{8}$. Można jednak również w owej przydawce widzieć znaczenie zacieśniające, określające w sposób formalny tych, których ma dotyczyć modlitwa: ma to być modlitwa za tych i tylko tych Żydów, których można określić jako „perfidi” i obejmująca ich ze względu na specyficzną „perfidia Judaica”. Znaczenia tego pojęcia należy szukać przede wszystkim w najbliższym kontekście samej modlitwy, zwłaszcza jeśli pierwotnie nie była istotnie związana $\mathrm{z}$ Wielkim Piątkiem ${ }^{9}$, a więc $\mathrm{z}$ kontekstem Pasji według św. Jana, a tym mniej z kontekstem pochodzącej z innej (jerozolimskiej) tradycji liturgicznej adoracji krzyża i „improperiów”. Ciąg modlitw wstawienniczych ma swoją własną logikę zakładającą taki obraz rzeczy, w którym świat łącznie z cesarzem jest już chrześcijański, lecz niejako na jego obrzeżach znajdują się jeszcze ci, którzy są bardziej zagrożeni niż rzesza chorych, utrapionych, więźniów, podróżujących i w ogóle „de quacumque tribulatione clamantium", gdyż nie zdając sobie sprawy z zagrożenia, w jakim ich stawia ich niewiara, sami za sobą nie wołają do Boga zbawiającego wszystkich, niewykluczającego nikogo ze swego miłosierdzia i nie pragnącego śmierci, lecz życia dla grzeszników. Są nimi właśnie „haeretici et schismatici”, , perfidi Judaei” i „pagani”. Zauważmy, że w wezwaniach do modlitwy ani pierwsi, ani ostatni nie są obdarzeni żadnym dodatkowym „epitetem”. W przeciwieństwie bowiem do etnicznego określenia „Judaei” pozostałe kategorie same z siebie wyrażają już ów wadliwy z chrześcijańskiego punktu widzenia stosunek do wiary, który czyni ich przedmiotem szczególnej troski i szczególnej modlitwy Kościoła. Wobec tego, chociaż nie można mieć specjalnej nadziei, że ci, którzy pierwsi zanosili do wszechmogącego, wiecznego Boga modlitwę ,pro illius populi obcaecatione" pamiętali dość żywo, iż „caecitas ex parte contigit in Israel” (Rz 11,25 Wlg) (zaślepienie jest przypisane w tej formule „owemu ludowi”"10 jako całoś-

${ }^{8}$ Pod koniec XIX w. Léon B loy, pragnący — według swych własnych słów - wbrew wszelkiej nadziei złożyć hold światu żydowskiemu i stanąć w jego obronie przeciw rodzącej się we Francji fali antysemityzmu, jest przekonany, że liturgia rzymska wskazuje w omawianym przez nas miejscu w sposób precyzyjny "la canaillerie profonde et parfaite, la scélératesse en abîme" (L. Bloy, Le Salut par les Juifs, ch. XXIV, Vienne 1923, s. 73; por. tamże, s. 6). Wiąże ją oczywiście wprost z wydaniem na śmierć Jezusa (Úbogiego) (tamże, s. 35).

${ }^{9}$ L. D u ch es ne twierdzi, że jeszcze w VIII w. orationes solemnes odmawiane byly także w Wielką Srodę (por. tenże, jw., s. 183).

${ }^{10}$ Jean A u ca gn e podkreśla, omawiając inne teksty kościelne dotyczące Żydów, uroczysty, „zasadniczy” („fondateur”) charakter zaimka ille w języku kościelnym (, ,in illo tempore”, „populus ille”); - por. tenże, L'Islam par rapport à l'unicité et la division du Peuple de Dieu, [w:] JeanMiguel G a rrigues, L'unique Israël de Dieu, Limoges 1987, s. 177-209. 
ci), to przecież w takim kontekście określenie perfidi ukazuje się jako wskazujące po prostu na ten aspekt formalny „wykrzywionej wiary” Żydów (wszystkich czy części) ze względu na który specjalna modlitwa za nich znalazła miejsce między modlitwą za heretyków i schizmatyków a modlitwą za pogan ${ }^{11}$.

Dalszy ciąg wezwania do modlitwy, który precyzuje jej treść, każe szukać wyjaśnienia sensu owej „perfidia Judaica” u św. Pawła. Intencja, „ut Deus et Dominus noster auferat velamen de cordibus eorum: ut, et ipsi agnoscant Jesum Christum", czyni bowiem wyraźną aluzję do 2 Kor 3,12-16, który w tłumaczeniu Wulgaty (mającej zapewne bezpośredni wpływ na ukształtowanie tekstu modlitwy) brzmi:

Habentes igitur talem spem, multa fiducia utimur: et non sicut Moyses ponebat velamen super faciem suam, ut non intenderent filii Israel in faciem eius, quod evacuatur, sed obtusi sunt sensus eorum. Usque in hodiernum enim diem, idipsum velamen in lectione veteris testamenti manet non revelatum, (quoniam in Christo evacuatur) sed usque in hodiernum diem, cum legitur Moyses, velamen positum est super cor eorum. Cum autem conversus fuerit ad Dominum, auferetur velamen.

Widzimy tu ten sam obraz zasłony zapadającej na serce, która uniemożliwia człowiekowi przejrzenie, zrozumienie Bożych tajemnic. Paweł zapożycza go z Wj 34,33-35, aby powiedzieć, że jak niegdyś synowie Izraela bali się patrzeć na odblask chwały Bożej na twarzy Mojżesza, tak dziś, czytając jego pisma nie są zdolni (dokąd nie zwrócą się ku Panu) przeniknąć ich sensu odsłaniającego się w Jezusie Chrystusie. Cofając się tedy od określenia perfidia poprzez objaśniające go w modlitwie obrazy velamen i obcaecatio do tekstów Pawłowych Rz 11,25 i 2 Kor 3,12-16 natrafiamy ostatecznie w tekście greckim listów na kategorię duchowej pôrôsis względnie pêrôsis ${ }^{12}$ - owego trudnego do pojęcia, lecz tak realnie i boleśnie doświadczanego przez Apostoła w trakcie jego pracy misyjnej (por. 2 Kor 11,24—26; Dz 13-28 passim) zasklepiania się, jak twardnie wulkaniczny tuf w zetknięciu z powietrzem, niektórych serc w kontakcie ze słowem Bożym, matowienia duchowego wzroku wobec spełniających się proroctw. Rzeczywistość duchowo groźna, wobec której człowiek staje bezradny - człowiek, ale nie Bóg, który dopuszczając ją do realizacji swych planów, mocen jest ją także uchylić (por. Rz 9,14-26) ${ }^{13}$; rzeczywistość mogą-

${ }^{11}$ Idąc za wspomnianym już artykułem E. Pe ter s o n a w „Ephemerides Liturgicae” i za nauką św. To masza z A k win u na temat rodzajów grzechu niewiary ( $\mathrm{II}^{\mathrm{a}}-\mathrm{II}^{\mathrm{ae}} \mathrm{q} .10$ a 5-6), Charles Journet będzie wykazywał, że starożytne określenie perfidia nie ma zasadniczo innego znaczenia niż pojęcie infidelitas $w$ teologii scholastycznej i w wypadku Żydów odnosi się do nieprzyjęcia spełnienia w Jezusie z Nazaretu przyjmowanych z wiarą zapowiedzi Starego Testamentu; por. tenże, Destinées d'Israël, Paris 1945, s. 139-146; L'Eglise du Verbe Incarné, t. II, Paris 1951, s. $763-817$.

${ }_{12}$ Por. Ulrich B e ck e r (z Osterwald), Indurimento, [w:] Dizionario dei concetti biblici del Nuovo Testamento, red. L. Coenen, E. B yreuther, H. Bieten hard, Bologna 1976, s. 848851.

${ }^{13}$ Por. Fadiey Lovsk y, La théologie paulinienne du Mystère d'Israël, [w:] J.-M. G a r rig u e, jw., s. 77-115, s. 98-105; Marie-Thérèse Hu gu e t, Mise à l'écart de la Maison d'Israël?, tamże s. $119-145$, s. $122-124$. 
cą wystąpić zawsze tam, gdzie Bóg objawiający swe przekraczające ludzkie myślenie misterium spotyka się ze skłonną do oporu i buntu wolnością człowieka, rzeczywistość zagrażająca więc w szczególny sposób stale Ludowi powołanemu do istnienia słowem niepojętego Boga - Izraelowi. Rzeczywistość poświadczona i doświadczona przez Mojżesza i Proroków, zawsze jednak z równoczesną nadzieją na przyszłe odrodzenie (por. np Lb 11,4-15; Pwt 9,6-29; 1Krl 18,17—21; Ez 2,4—9; czy wreszcie klasyczny tekst Iz 6,9—10, do którego odwołuje się w Rz 11,8 i Paweł). Rzeczywistość, którą św. Paweł wiąże w przytoczonym kontekście z niepowodzeniem swej ewangelizacji wśród rodaków, a nie $\mathrm{z}$ ich udziałem w wydaniu na śmierć Jezusa; $\mathrm{z}$ takim czytaniem przez nich Pisma, że nie widzą w nim tego, co dla Pawła jest radosną oczywistością dzięki wierze w Jezusa jako Chrystusa (-Mesjasza), a nie z decyzją Sanhedrynu w sprawie Rabbiego z Nazaretu; z pewną rzeczywistością trwającą „aż po dziś dzień", a nie z jednorazową zbrodnią.

Gdyby więc wrócić do biblijnych inspiracji omawianej modlitwy za Żydów, gdyby przy tym pamiętać, że Paweł mówiący o zasłonie na sercach synów Izraela zawsze podkreśla, że jest jednym z nich (por 2 Kor 11,$22 ; R z 11,1$ ) i wolałby sam być odrzucony przez Chrystusa dla ich zbawienia ( $\mathrm{Rz} 9,3$; por. 10,1), gdyby wreszcie (dalej w duchu powrotu do źródeł) w spowszedniałej formule prośby: „ut et ipsi agnescant Jesum Christum Dominum nostrum”, widzieć ukryty accusativus cum infinitivo, za którym stoi najbardziej podstawowe wyznanie chrześcijańskiej wiary (por. Rz 10,9; Flp 2,11), można by wyczytać w niej braterskie wołanie Kościoła za tymi, którzy w szczególny sposób dziedzicząc obietnice Boże (por. Rz 9,4) doznali w zetknięciu z ich spełnieniem (tak bardzo nieoczekiwanym) w Jezusie owego paraliżującego dalszy rozwój wiary porażenia, wobec którego przecież Miłosierdzie Wszechmocnego przynaglane modlitwami nie może być bezsilne; można by widzieć prośbę o największe dobro, prawdę, światło, bez którego wiara Izraela rozmija się z tym, ku czemu dąży: o rozpoznanie w Jezusie Mesjasza i Pana.

Bardzo trudno jest modlić się za błądzących bez poczucia wyższości ze znajdowania się na właściwej drodze (przed czym przestrzega i Paweł — por. $\mathrm{Rz}$ 11,18-19 - i sam Jezus - por. Łk 18,9-14), dużo łatwiej wyciągać źdźbło z cudzego oka, niż belkę z własnego. Już w samym tekście modlitwy, jakby nie osłabiać pejoratywnego znaczenia słowa perfidia, akcent spoczywa raczej na przerażającym ogromie zaślenienia, który ma podkreślić wielkość Miłosierdzia („etiam judaicam perfidiam... non repellis”) niż na bogactwie mesjańskich darów, o które się Je prosi; w konkluzji modlitwy można by się spodziewać jako wyniku poznania przez Żydów zaślepionych „światła Bożej prawdy, którą jest Chrystus”, czegoś więcej niż tylko „wyrwania ich z ciemności”, skoro św. Paweł w ich przyjęciu widzi źródło życia powstającego pośród 
śmierci (por. Rz 11,15; Ez 37,11-14) ${ }^{13 a}$. Gorzej jeszcze bywało z popularnym rozumieniem tej modlitwy, gdy widziano w niej błagania za przewrotnie perfidnymi „katami Pana"14, za ludem, któremu On „morze otworzył, by szedł suchą nogą", a który Mu w zamian „włócznią bok otworzył srogą"15. Dlatego w czasach, kiedy sam środek chrześcijańskiej Europy został porażony ślepotą dużo głębszą i stwardnieniem serc dużo straszniejszym, niż się to kiedykolwiek przydarzyło Izraelowi ${ }^{16}$ (aby się żadne stworzenie nie chełpiło wobec swego Stwórcy), zaczęły się pośród tych, którym Bóg pozwolił zachować serce wrażliwe i wzrok przenikliwy, podnosić głosy domagające się rewizji przynajmniej tłumaczeń wielkopiątkowej modlitwy ${ }^{17}$.

\section{Usunięcie stów „perfidi” $i$ „perfidia” przez Jana XXIII}

Pierwsze decyzje Stolicy Apostolskiej dotyczące modlitwy za Żydów w liturgii Wielkiego Piątku przyszły niedługo po zakończeniu II wojny światowej $^{18}$, 10 VI 1948 r. Swięta Kongregacja do spraw Obrzędów, zapytywana w sprawie właściwego sensu wyrażeń perfidi judaei i judaica perfidia i stosowności niektórych tłumaczeń na języki nowożytne, wydała deklarację, w której uznała za słuszne wyjaśnić jedynie, że nie należy ganić tych tłumaczeń, w których na określenie łacińskiej perfidia i perfidi użyto słów mających znaczenie infidelitas, infideles in credendo (niewierność, niewierni w tym, co wyznają) ${ }^{19}$. Wypowiedź niezwykle powściągliwa, stanowiąca jednak pewien pierwszy krok i pozwalająca na przykłady nie mające wszystkich obciążeń związanych ze sło-

13a Por. Ch. Jo u rnet, Destinées d'Israël, Paris 1945, s. 356-366; L. Bl o y, Le Salut par les Juifs, Vienne 1923, s. 120-121.

${ }_{14}^{14}$ Por. P. Guéranger, jw., s. 529; L. Bloy, jw., s. 67.

${ }^{15}$ Por. J. Si ed le cki, Spiewnik kościelny, Opole 1973, s. 74. Swiadomie czynię aluzję do tego właśnie wersetu polskiej parafrazy Popule menus. Otwarcie boku Jezusowego włócznią było w świetle J 19,32 n dziełem jednego z żołnierzy Piłata, a nie Ludu przeprowadzonego przez Morze Czerwone.

${ }_{16}$ Piszę tak ze względu na slowa pana: „Cokolwiek uczyniliście jednemu z tych braci moich najmniejszych, Mnieście uczynili" (Mt 25,40).

${ }_{17}$ Por. J. M a rit a i n, Lettre à la conférence du Seelisberg, [w:] Le Mystère d'Israël et autres essais, Paris 1965, s. 221-231, s. 230-231; Ch. J o u r n e t, Destinées d'Israël, Paris 1945, s. 143.

18 „Les expressions perfidi judaei et judaica perfidia employées dans la liturgie du Vendredi saint n'étaient pas sans heurter beaucoup de chrétiens, surtout après les crimes de la dermière guerre inspirés par l'antisémitisme" - pisze w redakcyjnej notatce pt. La modification de la prière pour les Juifs le Vendredi saint, „La Documentation catholique” z 5. 07.1959 (41:1959 kol. 842-844, kol. 842).

19 „In bina illa precatione qua sancta Mater Ecclesia in orationibus sollemnibus feriae sextae in Parasceve etiam pro populo hebraico Dei misericordiam implorat, haec verba occurrunt: perfidi iudaei et iudaica perfidia. Porro quaesitum est de vero sensu istius locutionis latinae, praesertim cum in variis translationibus ad usum fidelium in linguas vulgaris factis illa verba expressa fuerint locutionibus quae auribus istius populi offensivae videantur.

Sacra haec Congragatio, de re interrogata, haec tantum declarare censuit: Non improbari, in translationibus in linguas vulgares, locutiones quarum sensus sit infidelitas, infideles in credendo" (Deklaracja Swiętej Kongregacji Obrzędów z 10.06.1948, [w:] Acta Apostolicae Sedis [AAS] 40: 1948 s. 342). 
wem „perfidia" ${ }^{20}$. Następny niewielki krok uczyniono przy okazji bardziej gruntownej reformy liturgii Wielkiego Tygodnia wprowadzonej dekretem $\mathrm{Ma}$ xime Redemptionis Świętej Kongregacji do spraw Obrzędów z 16 XI $1955^{21}$. Nowe Ordo hebdomadae sanctae zawierało po wezwaniu do modlitwy za Żydów, tak jak w przypadku wszystkich pozostałych modlitw, wezwania „Oremus. Flectamus genua. Levate"22. Znosiło więc wyjątkowość zwyczajów związanych z modlitwą za Żydów i odbierało podstawę do związanych z tym komentarzy.

Krok decydujący uczynił papież Jan XXIII. Sprawując po raz pierwszy w czasie swego pontyfikatu liturgię wielkopiątkową 27 III 1959 r. w Bazylice św. Krzyża Jerozolimskiego w Rzymie, gdy doszło do słów „oremus et pro perfidis judaeis”, kazał raz na zawsze wykreślić słowo „perfidis”. Swięta Kongregacja do spraw Obrzędów jeszcze tego samego roku zmodyfikowała tekst w dwóch miejscach i drogą dyplomatyczną rozesłała do biskupów poszczególnych krajów ${ }^{23}$. Poprawiony tekst brzmiał teraz następująco ${ }^{24}$ :

\section{Oremus et pro Iudaeis: \\ ut Deus et Dominus noster auferat velamen de cordibus eorum: ut et ipsi agnoscant Iesum Christum Dominum nostrum. \\ Oremus. Flectamus genua. Levate. \\ Omnipotens sempiterne Deus, qui Iudaeos etiam a tua misericordia non repellis:}

${ }^{20} \mathrm{Na}$ przykład wydany w r. 1955 Missel quotiden, vespéral et rituel ze wstępem, przekładem i przypisami Dom Gé r a r d a z opactwa w Clervaux (Turnhout-Paris) daje przekład: „Prions aussi pour les Juifs infidèles [... ]”; „Dieu tout-puissant et éternel, qui ne refusez votre miséricorde même pas aux Juifs parjures [...." (s. 709).

${ }^{21}$ Por. AAS $47: 1955$ s. 838 - 841. Ani sam dekret, ani następująca po nim instrukcja (s. 842847) nie sygnalizują interesującej nas zmiany.

${ }^{22}$ Ordo hebdomadae sanctae instauratus. Editio typica, Typis Polyglottis Vaticanis 1956, s. 91; por. wyżej przypis 18 . Wspomniany powyżej Missel quotiden z $1955 \mathrm{r}$. zawiera między stroną 578 a 579 wstawkę wyszczególniającą zmiany wprowadzone przez nowe Ordo. Jest tam wspomniana również zmiana, o której mowa: „En priant pour la conversion des juifs, on se met à genoux comme pour toutes les autres oraisons" (s. $578 \mathrm{~h}$ ). Natomiast w samym tekście mszalika występuje jeszcze zniesiona przez nowe Ordo różnica (s. 709).

23 „Warto tu podkreślić szczegół, jaki podało Radio Watykańskie — pisał w „Tygodniku Powszechnym" z 10. 04. 1959 r. redaktor Kroniki religijnej, omawiając uroczystości Wielkiego Tygodnia w Rzymie - a mianowicie, że w czasie czytania modlitw za całą ludzkość podczas celebry wielkopiątkowej w modlitwie ósmej pro perfidis Judaeis papież kazał wykreślić na zawsze słowo 'perfidis" (s. 7). „Un dernier pas a été fait dans ce sens par S.S. Jean XXIII - pisze w cytowanym już sprawozdaniu „La Documentation Catholique” po wymienieniu dwóch poprzednich modyfikacji - qui, pour la cérémonie du Vendredi saint de cette année à laquelle il a assisté en l'église romaine Sainte Croix de Jérusalem, a fait supprimer les mots perfidi et perfidia. Cette décision se trouve aujourd'hui sanctionnée par une décision de la Sacré Congrégation des Rites. Voici le texte que cette Congrégation a prié S. Exc. le nonce apostolique en France de bien vouloir transmettre aux évêques et qui a été reproduit par plusieurs 'Semaines religieuses': 'Par souveraine disposition de S.S.Jean XXIII, la prière liturgique du Vendredi saint pro conversione iudaeorum a été modifiée comme il suit [:...] (kol. 842-843). Cytowana tu dyspozycja Kongregacji nie została odnotowana w Acta Apostolicae Sedis.

${ }_{24}$ Tamże, kol. 843-844, poświadczony także przez Missale Romanum [...] editio iuxta typicam, Novi Eboraci, zatwierdzony dekretem kard. F. Spellmana z 11. 04. 1962 r. (s. 176). Podzial na wiersze pochodzi od autora artykułu. 
exaudi preces nostras, quas pro illius populi obcaecatione deferimus, ut agnita veritatis tuae luce, quae Christus est, a suis tenebris eruantur.

Per eumdem Dominum. Amen.

Decyzja Jana XXIII była z pewnością gestem bardzo potrzebnym, by uciąć wszystkie krzywdzące skojarzenia i otworzyć drogę Kongregacji do śmielszego działania. Nie tak łatwo jednak jednym pociągnięciem pióra poprawić tekst mający swą wewnętrzną logikę. Choć na pierwszy rzut oka zniknęło z niego to, co stanowiło największy kamień obrazy, to przy bliższym przyjrzeniu się mu, paradoksalnie stał się on teraz w swej obiektywnej treści bardziej „,antyżydowski”, niż był na początku, rzeczywiście niesprawiedliwy.

Po pierwsze modlitwa stała się teraz modlitwą za Żydów jako takich, bez żadnych ograniczeń co do zakresu czy formalnego aspektu, podczas gdy treść jej zasadniczo pozostała niezmieniona. Wynikałoby z niej, że jest sprawą przesądzoną, iż na sercach wszystkich Żydów, dlatego tylko, że są Żydami, zalega zasłona, że są zaślepieni i potrzebują wyrwania ze swoich ciemności. Nie pozostawia się Bogu (jak to było przynajmniej formalnie w formule „pro perfidis Judaeis") osądu co do tego, kto de facto jest objęty tą modlitwą; zapomina się też, że Kościół od początku składał się i nadal składa z wybranych spośród Żydów i narodów. W uproszczonej formule nie dopuszcza się świadomości istnienia synów Izraela, którzy już poznali, że Jezus jest Mesjaszem i Panem naszym.

Po drugie w samej oracji, gdzie znów „Żydzi” bez żadnych bliższych określeń zajęli miejsce zajmowane dotąd przez ,perfidiam judaicam” pozostało całkiem teraz nieusprawiedliwione „etiam”. O ile można było dyskutować, czy rzeczywiście perfidia judaica jest rodzajem oporu wobec Bożej łaski wystawiającym Jego Miłosierdzie na szczególnie ciężką próbę (taka supozycja starego tekstu mogła w każdym razie wskazywać jakoś na pamięć autorów o szczególnym wybraniu Żydów), o tyle nie można zrozumieć zdumienia poprawionego tekstu wobec faktu, że Bóg „nawet Żydów” nie wyłącza ze swego miłosierdzia - wszakże to do nich właśnie „należą przybrane synostwo i chwała, przymierza i nadanie Prawa, pełnienie służby Bożej i obietnice; do nich należą praojcowie, z nich również jest Chrystus według ciała" ( $\mathrm{Rz} 9,4-5)$; to oni są ze względu na przodków przedmiotem szczególnej miłości Boga (por. Rz 11,28).

Tekst nie mógł taki pozostać i rzeczywiście niedługo taki pozostał. Istniały dwie drogi wyjścia: albo przywrócić jakieś określenie specyfikujące, o kogo chodzi w modlitwie, albo też tak przekształcić samą modlitwę, żeby mogła obejmować rzeczywiście wszystkich Żydów. Kościół poszedł tą drugą drogą. 
„Variationes” z 1965 r.

Sobór Watykański II swą konstytucją o liturgii świętej z 4 XII 1963 r. zapowiedział daleko idące zmiany w liturgii. Konstytucja dogmatyczna o Kościele z 21 XI 1964 r. na nowo ustawiała perspektywę ludu Bożego i przynależności do niego, przypominając, że wśród tych, którzy „w rozmaity sposób przyporządkowani są” do niego, na pierwszym miejscu stoi „populus ille”, któremu zostały dane przymierza i to wszystko, o czym mówi św. Paweł w Liście do Rzymian ( $\mathrm{Rz} 9,4-5 ; 11,28-29)$, ,populus secundum electionem carissimus propter patres"25. Od początku swych obrad Sobór ma też świadomość potrzeby wyraźnego ustosunkowania się Kościoła do Żydów i potępienia antysemityzmu. W takim kontekście wolno się było spodziewać gruntownej przeróbki wielkopiątkowej modlitwy za Żydów. Rzeczywiście wprowadzono ją jeszcze przed zakończeniem Soboru, a nawet przed uchwaleniem Deklaracji o stosunku Kościoła do religii niechrześcijańskich (z 28 X 1965 r.).

W związku ze zbliżającą się Wielkanocą 1965 r., aby zadośćuczynić prośbie biskupów, którzy zgodnie z zaleceniem konstytucji o liturgii św. (SC 57 \$1 1a) chcieli jeszcze tego roku koncelebrować ze swymi kapłanami Mszę Krzyżma w Wielki Czwartek, Święta Kongregacja Obrzędów w porozumieniu z Radą dla wprowadzenia w życie konstytucji o liturgii, wprowadziła dekretem z 7 III 1965 r. zmiany dotyczące obrzędów Wielkiego Tygodnia. Dekret wyjaśnia, że oprócz zmian związanych z przystosowaniem liturgii Wielkiego Czwartku do koncelebry postanowiono przy okazji wprowadzić też zmiany do niektórych z orationes solemnes Wielkiego Piątku tak, aby przystosować je do „ducha i dekretów Soboru Watykańskiego II dotyczących spraw ekumenicznych"26. Variationes in Ordinem Hebdomadae Sanctae inducendae zawierały faktycznie cztery zmienione formuły modlitw wstawienniczych z Wielkiego Piątku: 1. Pro Sancta Ecclesia; 7. Pro unitate Christianorum; 8. Pro Iudaeis; 9. Pro nondum in Christo credentibus. Zmieniony tekst modlitwy za Żydów brzmiał teraz tak ${ }^{27}$ :

Oremus et pro Iudaeis:

ut Deus et Dominus noster faciem suam super eos illuminare dignetur; ut et ipsi agnoscant omnium Redemptorem, Iesum Christum Dominum nostrum.

25 „Li tandem qui Evangelium nondum acceperunt, ad Populum Dei diversis rationibus ordinantur. In primis quidem populus ille cui data fuerunt testamenta et promissa et ex quo Christus ortus est secundum carnem (cfr. Rom. 9,4-5), populus secundum electionem carissimus propter patres; sine poenitentia enim sunt dona et vocatio Dei (cfr. Rom. 11,28-29)" (LG 16).

26 „Insuper, hac eadem arrepta occasione, qua nonnullae variationes in Ordinem Hebdomadae sanctae inducuntur, congruum visum est etiam unam aliamvae locutionem in orationibus sollemnibus feriae VI in Passione et Morte Domini occurrentem aptare, ut spiritui et decretis de re oecumenica sacrosancti Concilii Vaticani II congrueret" (Variationes in Ordinem Hebdomadae sanctae inducendae. Editio typica. Typis Polyglottis Vaticanis 1965, s. 5; por. AAS 571965 s. $412-$ 413).

${ }^{27}$ Variationes..., s. 21-22. 
Oremus. Flectamus genua. Levate.

Omnipotens sempiterne Deus, qui promissiones tuas Abrahae et semini eius contulisti:

Ecclesiae tuae preces clementer exaudi;

ut populus acquistionis antiquae

ad Redemptionis mereatur plenitudinem pervenire.

Per Dominum.

[Omnes R.] Amen.

Zauważmy, że o ile pierwsza część (wezwanie do modlitwy) jest przeróbką dawnego tekstu, o tyle sama oracja jest właściwie całkowicie nowa. Przyjrzyjmy się najpierw zmienionemu wezwaniu. Pozostało ono wezwaniem do modlitwy za Żydów bez żadnych bliższych określeń. Z dwóch poddawanych przez dawne wezwanie intencji modlitwy za nich pierwsza została całkowicie zmieniona, druga - wzbogacona o dodatkowe wyjaśnienie. Na pierwszym miejscu nie chcemy już prosić Boga i Pana naszego o zdjęcie zasłony z ich serc, lecz o rozpromienienie nad nimi Jego oblicza. Zostaje wycofany obraz Pawłowy dotyczący tych, którzy nie rozpoznają w Jezusie Mesjasza, a wprowadzony fragment treści błogosławieństwa arcykapłańskiego (Lb 6,25) ${ }^{28}$ dotyczącego wszystkich Synów Izraela (por. Lb 6,23). Podtekst nowotestamentalny zostaje zastąpiony odwołaniem się do Starego. Choć określenie Iudaei nie zostało wprost doprecyzowane, pierwsza intencja modlitwy odsyła nie do myśli o tej części Izraela, którą do czasu dotknęła zatwardziałość (por. Rz 11,25), lecz do pamięci o wszystkich, nad którymi Bóg nakazał Aaronowi i jego synom wzywać swego błogosławieństwa. Wyraźne przejście od patrzenia poprzez to, co dzieli i może stać się okazją do wynoszenia się nad braci, do ukazania tego, co łączy i nakazuje szacunek. Co prawda sam dobór tej właśnie części błogosławieństwa, tego obrazu rozpromienienia się Bożego Oblicza nad Izraelem mającego także paralele w Psalmach (Ps 67/66,2; 31/30,17; 119/118, 135; por. też $4,7)$ skłania do przypuszczenia, że autorzy zmiany wciąż mają przed oczyma rzeczywistość ujętą przez św. Pawła w obrazie zdjęcia zasłony z serca, którą pragnął wyrazić w bardziej pozytywny i delikatniejszy sposób. W kontekście psalmu $67 / 66^{29}$ oraz w świetle prośby Mojżesza i odpowiedzi Boga w Wj 33, 13-23 może bowiem chodzić w intencji autorów o tę bliskość i bezpośredniość spotkania z Bogiem, której Bóg odmówil na Synaju Mojżeszowi, a której zniszczenie ma być warunkiem poznania drogi Pana i Jego zbawienia pośród

28 Jest to widoczne zwłaszcza w nowym wydaniu Wulgaty, gdzie w. 25 brzmi: „Illuminet Dominus faciem suam super te et misereatur tui!" (Nova Vulgata Bibliorum Sanctorum, Libraria Editrice Vaticana 1979). Dawne wydania Wulgaty mają w w. 25: „ostendat Dominus faciem suam tibi et misereatur tui" (por. np. La Sainte Bible. Texte latin et traduction française... t. II, Paris 1946, s. 275),

${ }^{29} \mathrm{~W}$ pozostałych trzech psalmach kontekst jest indywidualny: rozjaśnienie czy wzniesienie się oblicza Bożego na zwiastować wyrwanie modlącego się z ucisku. 
wszystkich ludów - a więc (w perspektywie chrześcijańskiej, w szczególności Pawłowej) to, czego, w odróżnieniu od mających zasłonę na sercu, doświadczają trwający w Chrystusie, z odsłoniętą twarzą wpatrując się w jasność Pańską jak w zwierciadle (por. 2 Kor 3,18). Zresztą pozostawienie niezmienionej co do istoty drugiej części wezwania potwierdza taką właśnie interpretację: rozjaśnienie oblicza Pańskiego ma spowodọwać rozpoznanie „omnium Redemptorem, Iesum Christum Dominum nostrum”. Dodanie do dawnej formuły wyjaśnienia, że chodzi o „Odkupiciela wszystkich” świadczy, iż nie rozumie się już zwrotu „Iesum Christum Dominum nostrum” jako samoistnej wypowiedzi (accusativus cum infinitivo), lecz tylko jako bardziej ozdobne i uroczyste wskazanie Osoby Jezusa. Nie wydobyto przy tym z cienia zawartej już w pierwotnej formule i bezpośrednio związanej z Izraelem kategorii Mesjasza (=Chrystusa) (być może jako zbyt obciążonej bolesnymi dziejami niemal dwutysiącletniej kontrowersji), lecz spróbowano wprowadzenia nowej z odwołaniem się do jej uniwersalistycznego znaczenia — choć i ona przecież, sięgając korzeniami Starego Testamentu, w pierwszym rzędzie odnosi się do Jakuba i Syjonu (por. Iz 59,20 w kontekście całego rozdziału; por. Rz 11,26). Podkreślenie, że chodzi o rozpoznanie przez Żydów Jezusa jako Odkupiciela wszystkich dźwięczy w kontekście całego wezwania nutą specyficznie chrześcijańskiej niecierpliwości ${ }^{30}$ pod adresem tych, którzy przecież pierwsi powinni by byli się na tym poznać. Ważniejsze jednak wydaje się to, że przez tak sformułowaną intencję modlitwy pozostaje się, mimo perspektywy otwartej zmianą pierwszej jej części, w kręgu takiego rozumienia pojęcia „Iudaei”, które zakłada, że chodzi tylko o tych Żydów, którzy jeszcze nie poznali Odkupiciela wszystkich Jezusa Chrystusa Pana naszego. Zobaczmy, jaką perspektywą ma sama oracja.

Pozostał w niej niezmieniony tylko adres: „Omnipotens sempiterne Deus, qui” i prośba o wysłuchanie modlitwy: „preces ... exaudi”; sprecyzowany został podmiot zanoszący modlitwę (Ecclesia Dei) i sposób wysłuchania (clementer). Zmieniła się całkowicie racja, na którą powołują się proszący: nie jest nią już miłosierdzie, które „nawet Żydów” nie odrzuca, lecz obietnice uczynione Abrahamowi i jego potomstwu. Zmienil się formalny przedmiot prośby: nie prosi się już o wyrwanie z ciemności będące następstwem poznania światła Bożej prawdy, którą jest Chrystus, lecz o zasłużenie na dojście do pełni Odkupienia; usunięto też dawny motyw prośby (obcaecatio) i wreszcie - co może dla nas najbardziej interesujące - spróbowano dokładniej określić, kogo modlitwa dotyczy (,populus acquisitionis antiquae” zamiast dawnego ogólnego „populus ille").

30 Owa niecierpliwość wywoływala już w czasach apostolskich pytania dające okazję św. Pawłowi do rozwinięcia tematu misterium Izraela (por. Rz 9,6n). W bardzo plastyczny sposób daje jej wyraz L. B loy w Le Salut par les Juifs, próbując nią wytłumaczyć antyżydowskie ekscesy w średniowieczu (por. zwłaszcza rozdzialy: XV, XX, XXIII). 
Wprowadzenie przysłówka clementer równoważy w nowym tekście brak wyraźnego wspomnienia miłosierdzia Bożego, co było ceną zapłaconą za wyeliminowanie nieszczęśliwego „Iudaeos etiam” i wprowadzenie bardzo przekonywającego w tym miejscu, bardzo biblijnego (por. choćby Wj 32,13; Pwt 9,27; Ps 105/104,42; Iz 45,23; 46,4; Ez 20,42—44; a także Łk 1,54n; 1,72n) odwołania się do wierności Boga obietnicom uczynionym na wieki (por. Rz 11,29). Formuła ta nawiązuje najbardziej bezpośrednie do Ga 3,16 („Abrahae dictae sunt promissiones et semini eius"), gdzie św. Paweł (podobnie jak Mojżesz w dramatycznym momencie dziejów Izraela i sam Pan Zastępów w wyroczniach Ksiąg Izajasza i Ezechiela) przypomina ostateczną instancję, na której opiera się nadzieja na Bożą łaskawość u wszyśtkich, którzy są dziedzicami poprzysiężonych przez Boga obietnic dla Abrahama, Izaaka, Izraela ( Rdz $12,2-3,7 ; 13,15-17 ; 17,4-8 ; 22,16-18 ; 26,24 ; 28,13-15)$. Jest to wspólna podstawa nadziei tak dla „ludu pradawnie nabytego”, za którym w modlitwie się prosi, jak i dla świętego zgromadzenia (Ecclesia Dei), które przez wiarę i chrzest przyobleczone w Chrystusa-Semen Abrahae (por. Ga 3,79.16.22.27.29) ma prawo $\mathrm{z}$ ufnością tę prośbę zanosić.

Jest to prośba o to, aby „populus acquisitienis antiquae” zasłużył („mereatur”) na dojście do „pełni Odkupienia”, na to by osiągnąć „Redemptionis plenitudinem". Samo zestawienie: redemptionis plenitudo, nie ma odpowiednika w Piśmie św. Oba zestawione słowa mają głębokie zakorzenienie w Biblii. Dwa teksty w szczególności wydają się przybliżać sens wyrażonej nimi prośby. Najpierw zakończenie psalmu De profundis z jego „copiosa redemptie”:

[...] speret Israel in Domino, quia apud Dominum misericordia, et copiosa apud eum redemptio.

Et ipse redimet Israel

ex omnibus iniquitatibus eius [Ps 130/129, 7-8].

Po wtóre, zwłaszcza gdy się pamięta, że prośba odpowiada na wezwanie do modlitwy o poznanie Jezusa Chrystusa jako Odkupiciela a zastępuje dawną prośbę, w której Chrystus nazwany był Lux veritatis Dei, przychodzi na myśl 1 Kor 1,30, gdzie Chrystus Jezus przedstawiony jest jako Ten, „qui factus est nobis sapientia a Deo, et iustitia, et sanctificatio, et redemptio". Zauważmy, że w tekście Variationes wyraz „Redemptionis” ma duże $R$. Tak więc w nowej wersji modlitwy prosi się o to, co stanowi przedmiot nadziei Izraela i jego błagania w Psalmach z dyskretnym jakby wskazaniem na Tego, w którym wszystkie obietnice (premissiones) Boże stały się „tak” (por. 2 Kor 1,20) i w którym zamieszkuje omnis plenitudo (Kol 2,9). Jednocześnie zestawienie: Redemptionis plenitudo, nasuwa myśl, że rzeczywistość odkupienia, o której pełnię się modlimy jako o kres drogi, jest już jakoś, choć w sposób niepełny, obecna 
w życiu tych, za których się modlimy. Upodobnia to „populum acquisitionis antiquae" do modlącego się zań zgromadzenia tych, co otrzymawszy już pierwociny Ducha, całą istotą wzdychają przecież oczekując odkupienia ciała (por. Rz 8,23n). Ustawia taką perspektywę, w której treść modlitwy może się formalnie, choć zapewne nie jednoznacznie, lecz w sposób analogiczny, odnosić zarówno do Kościoła jak i do Izraela, a więc w szczególności i do ich części wspólnej; nie rozdziela Żydów na tych, którzy nie przyjęli Jezusa jako Mesjasza i tych, którzy Go przyjęli, lecz obejmuje wspólną modlitwą cały Lud określony przez jego korzenie.

Taki wydaje się też sens określenia: populus acquisitionis antiquae ${ }^{31}$. Ciekawe to określenie odsyła wyraźnie do 1 Listu św. Piotra, a przezeń pośrednio do Księgi Wyjścia i Przymierza zawartego na Synaju. W 1 P 2,9 czytamy w odniesieniu do Kościoła (ściślej „,do wybranych [...] według przewidzenia Boga Ojca na uświęcenie w Duchu, posłuszeństwo i pokropienie krwią Jezusa Chrysusa” — por. 1P 1,1-2): „Vos autem genus electum, regale sacerdotium, gens sancta, populus acquisitionis" 32 . Otóż określenia: regale sacerdotium, gens sancta, pochodzą wprost z Wj 19,6 ${ }^{33}$, gdzie Pan objaśnia Mojżeszowi, jaka zaistnieje różnica między „domem Jakuba” a wszystkimi narodami, jeśli synowie Izraela będą słuchać głosu Bożego i strzec Jego Przymierza. Wprawdzie do Pana należy cała ziemia, ale oni będą szczególną własnością, królestwem kapłanów, świętym szczepem. Określenie populus acquisitionis, (w oryginale $1 \mathrm{P}$ laos eis peripoiêsin) łączy się również w sposób wyraźny choć niedosłowny z ideą segulläh (Septuaginta : periousios) z Wj 19,5: lud, który jest szczególną własnością Boga jest też ludem, do którego On nabył szczególnych praw: przecież przywiódł go ku sobie niosąc go z kraju niewoli przez pustynię jak orzeł niesie swe pisklę na skrzydle (por. Wj 19,4) ${ }^{34}$. W tym znaczeniu nabyl go sobie. Jeśli, uzupełniając zwrot z $1 \mathrm{P}$, omawiana przez nas modlitwa dodaje ,acquisitionis antiquae", to ma, jak się zdaje, na myśli ów podwójny kontekst wyrażenia „populus acquisitionis” i podwójne „nabycie”: tamto pierwsze — przez wyprowadzenie z Egiptu i opiekę na pustyni, o którym mowa w Księdze Wyjścia i to drugie, ceną krwi Chrystusa — niepokalanego Baranka (por. 1 P 1,19), do którego bezpośrednio odnosi się określenie św. Piotra. Chodzi zatem o lud, który zostal określony, ukonstytuowany przez tamto dawne nabycie na szcze-

${ }^{31}$ Wolno przypuszczać u autorów odnowioną świadomość tego, że Kościól od początku i stale składa się z Żydów i narodów, w modlitwie opracowanej po ukazaniu się konstytucji dogmatycznej o Kościele (Lumen gentium), gdzie czytamy (po zacytowaniu Jr 31,31-34): „Quod foedus novum Christus instituit, novum scilicet testamentum in suo sanduine (cfr. 1 Cor. 11,25), ex Iudaeis ac gentibus plebem vocans, quae non secundum carnem sed in Spiritu ad unitatem coalesceret, essetque novus populus Dei" (LG 9).

${ }^{32}$ Nova Vulgata (jw., s. 2111) ma: „populus in acquisitionem”.

${ }^{33}$ Nova Vulgata..., s. 105: „Si ergo audieritis vocem meam et custodieritis pactum meum, eritis mihi in peculium de cunctis populis; mea est enim omnis terra. Et vos eritis mihi regnum sacerdotum et gens sancta (Ex 19,5-6)".

${ }^{34}$ Por. E. B y re uthe r, Peripoieomai, [w:] Dizionario..., s. 1336-1337. 
gólną własność przez Boga, o lud wcześniej powołany, by głosić chwałę Boga (por. 1P 2,10 i Ef 1,11-14). Kościół zatem, świadomy swej zażyłości z wszechmogącym, wiecznym Bogiem, będąc Jego szczególną własnością, uczestnicząc w Chrystusie w obietnicach Bożych danych Abrahamowi i jego potomstwu, przypomina Bogu te obietnice i lud, któremu obietnice Boże zostały powierzone od początku i który Bóg sobie nabył na szczególną własność już od dawna, prosząc, by lud ten w całości i w pełni dostąpił rzeczywistości Odkupienia dokonanej przez Chrystusa i mającej się w pełni objawić wraz z Jego powtórnym przyjściem w chwale.

Oracja zatem w całości i konsekwentnie (w przeciwieństwie do poprzedzającego ją wezwania) jest modlitwą za lud Izraela jako taki, jako ukonstytuowany przez Boga, przez jego obietnicę i dotyczy dóbr, których Izrael jako taki ma prawo na mocy tejże obietnicy z ufnością oczekiwać (por. Rz 11,29) ponad podziałem, jaki się w jego łonie dokonał i dokonuje w ciągu wieków ze względu na Osobę Jezusa. Dotyczy tych dóbr, których oczekuje (choć w inny sposób, na innym etapie) również Kościół Chrystusowy jako taki, (Kościół powołany spośród Żydów i narodów). Tak więc w wersji modlitwy za Żydów wprowadzonej do liturgii Wielkiego Piątku przez Variationes z 1965 r., mimo daleko idącego przeobrażenia pierwotnego tekstu, widzimy nadal pewną niekonsekwencję, mianowicie pewien rozziew między wezwaniem do modlitwy, które formalnie nadal dotyczy Żydów nieuznających w Jezusie Odkupiciela a samą oracją wyrażająca prośbę za lud Izraela jako taki. I ta formuła nie miała jednakże długo pozostać oficjalną modlitwą Kościoła ${ }^{35}$.

\section{Modlitwa za Żydów w mszale Pawta VI (1970)}

Odwołując się do postanowień Soboru Watykańskiego II, w szczególności do numerów 21, 50, 51, 58 konstytucji o Liturgii świętej, Paweł VI Konstytucją Apostolską Missale Romanum z 3 IV 1969 r. zarządził i ogłosił wprowadzenie odnowionego mszału rzymskiego mającego, między innymi, jaśniej wyrażać święte tajemnice i ułatwić wiernym pobożny i czynny udział w liturgii. Konstytucja zwraca uwagę na przerobienie tekstów wielu oracji, które zostały podjęte tak dla dostosowania do potrzeb nowych czasów jak i dla przywrócenia zapomnianych formuł ${ }^{36}$. W kontekście tych zmian, w nowym Missale Romanum promulgowanym w Wielki Czwartek 26 III $1970 \mathrm{r} .{ }^{37}$ uległa dalszej zmianie wielko-

35 W Polsce, dzięki Mszatowi rzymskiemu tacińsko-polskiemu z r. 1968, przetrwała do r. 1986.

36 Por. Constitutio Apostolica „Missale Romanum", AAS 61:1969 s. 217-222; Missale Romanum ex Decreto Sacrosancti Oecumenici Concilii Vaticani II instauratum auctoritate P a u li P. P. VI promulgatum. Editio typica altera, Typis Polyglottis Vaticanis 1975, s. 11-16: „In quibus [i.e. in Temporale, Sanctorale, Commune Sanctorum etc.] peculiaris quaedam diligentia ad orationes adhibita est, quae non solum numero auctae sunt, ut novis horum temporum necessitatibus novae responderent, sed etiam vetustissimae ad antiquorum textuum fidem redditae" (tamże, s. 15).

${ }^{37}$ Por. tamże, Decretum Sacrae Congregationis pro Cultu Divino, s. 9. 
piątkowa modlitwa za Żydów. W aktualnie obowiązującym mszale rzymskim brzmi ona następująco ${ }^{38}$.

Oremus et pro Iudaeis, ut, ad quos prius lecutus est Dominus Deus noster, eis tribuat in sui nominis amore et in sui foederis fidelitate proficere.

(Oratio in silentio. Deinde sacerdos:) ${ }^{39}$

Omnipotens sempiterne Deus, qui promissiones tuas Abrahae eiusque semini contulisti, Ecclesiae tuae preces clementer exaudi, ut populus acquisitionis prioris ad redemptionis mereatur plenitudinem pervenire. Per Christum Dominum nostrum. [R]. Amen. ${ }^{40}$

Tym razem gruntownej przemiany doznało wezwanie, z którego dawnej wersji pozostał tylko pierwszy wiersz, natomiast oracja została jedynie w dwóch miejscach lekko poprawiona: w określeniu „populus acquisitionis” słowo ,antiquae” zostało zastąpione słowem „prioris”, a w słowie „redemptionis" wyeliminowano duże $R$. Wydaje się, że w pierwszym wypadku chodziło o wprowadzenie takiego synonimu przymiotnika „,antiqua”, który by mówił tylko o pierwszeństwie w czasie określonego nim nabycia, a nie nasuwał myśli o jego nieaktualności nie pasującej zresztą do bliskiego kontekstu odwołania się do nieodwołalnych obietnic Bożych dla Abrahama i jego potomstwa. Usunięcie zaś dużego $R$ ukrywa niejako myśl o samym Odkupicielu, o którym nie ma zresztą już mowy w nowej wersji wezwania, tak że interpretacja zasadniczej prośby pozostaje bardziej otwarta. Przeobrażenie zaś, jakiego doznało wezwanie do modlitwy dostosowało je do perspektywy, jaką ma nowa oracja. Przede wszystkim dodane określenie wyjaśniające, jak należy rozumieć termin „Iudaei”, określenie korespondujące wyraźnie (już na płaszczeźnie samego słownictwa: prius — prioris) z określeniem „populus acquisitionis prioris” oracji. „Iudaei” to ci, ,,ad quos prius locutus est Dominus Deus noster”. Tak więc do dwóch tytułów nadprzyrodzonej tożsamości Żydów występujących w samej

${ }^{38}$ Editio typica altera z 27.03.1975r. nie wprowadziła w tym miejscu już żadnej zmiany. Por. Missale Romanum... Editio typica 1970, s. 254 z Missale Romanum... Editio typica altera 1975, s. 254.

${ }^{39}$ Nowy mszał pozostawił do rozstrzygnięcia krajowym konferencjom episkopatu kwestię zachowania lub zniesienia zwyczaju przyklękania i powstawania po wszystkich wezwaniach wielkopiątkowej modlitwy powszechnej: „Conferentiae Episcopales praevidere possunt acclamationem populi ante orationem sacerdotis, vel statuere ut servetur tradita in vitatio diaconi Flectamus genua. - Levate cum genuflexione omnium ad orationem in silentio" (Missale Romanum... Editio typica altera 1975 , s. 251).

${ }^{40}$ Tamże, s. 254. Podział na wiersze według tegoż Missale Romanum. 
oracji: obietnic Bożych i szczególnego nabycia przez Boga zostaje dołączony trzeci-Boże objawienie, przemówienie przez Boga. Wiąże się on zresztą mocno z pierwszym zwłaszcza poprzez brzmiącą w nim aluzję do ostatnich wersetów Magnificat (,sicut locutus est ad patres nostros, Abraham et semini eius in saecula" — Łk 1,55 Wlg). We wszystkich trzech przypadkach chodzi o Boży przywilej poprzez który Izrael wyprzedza w czasie i jednocześnie jest podobny do Kościoła Chrystusowego. Przy takim określeniu, kogo ma się na myśli w wezwaniu do modlitwy, nie mogły pozostać niezmienione poddawane intencje. Przepadła przy tym aluzja do błogosławieństwa Aaronowego wprowadzona przez Variationes z 1965 r., co może dodatkowo świadczyć, jak była ona związana w kontekście wezwania z perspektywą „zdjęcia zasłony” pierwotnego tekstu. Wprowadzono na to miejsce wezwanie do modlitwy o postęp, wzrost w tym, co stanowi o wierności Izraela w jego odpowiedzi na Boże wezwanie: amor nominis Dei i fidelitas foederis Dei. Zestawienie tej intencji z zasadniczą prośbą samej oracji nasuwa myśl, że postęp Żydów (oczywiście taki postęp, którego udzielić może tylko sam Pan i Bóg nasz) w miłości Jego Imienia i w wierności Jego przymierzu sprzyja, leży na linii dojścia przez nich do pełni odkupienia. Dwa występujące tu pojęcia biblijne: Imienia (nomen-onoma szèm) i przymierza (foedus - diathêkê - berit) uzmysławiają wyraźniej, niż wcześniejsze (ludu, nabycia, obietnic) swą nieciągłość w ciągłości między Nowym a Starym Testamentem, między żydowskim a chrześcijańskim rozumieniem tych samych formuł. O ile wspólne jest najwyższe przykazanie miłości Boga (Pwt 6,5; Mt 22,37), o tyle Imię, przywołujące na myśl stwórcze i zbawcze działanie Boga w przeszłości, teraźniejszości i przyszłości (np. Wj 3,6; 20,$2 ; 34,5-8 ;$ Iz 43,1-3. 18-21) i będące niejako uosobieniem Jego samego w Jego wyjściu ku człowiekowi (por. Ps 54/53,3; 89/88,25) to Imię, które w Starym Testamencie związane jest $\mathrm{z}$ objawioną Mojżeszowi treścią świętego tetragramu $(\mathrm{Wj} 3,14)$, w perspektywie Nowego jest niesione przez Tego, który, istniejąc zanim Abraham stał się, dał je poznać w swym paschalnym wywyższeniu (por. J 8,58.28; 17,6.11.26; dz 5,41) ${ }^{41}$, tak że miłość Imienia staje się miłością konkretnej Osoby, która przyjąwszy postać sługi staje się obrazem Niewidzialnego (por. Flp 2,6-11; Kol 1,15). Jeszcze wyraźniej różnica interpretacji występuje w odniesieniu do prośby o wierność przymierzu: przymierze bowiem zawarte na podstawie słów Bożych spisanych przez Mojżesza i przypieczętowane krwią zwierząt ofiarnych (por. Wj 24,3-8; Hbr 9, 16-21), złamane przez naród miało zostać „,po owych dniach” zastąpione nowym, doskonałym, połączonym z odpuszczeniem win (por. Jr 31,31-34) i chrześcijanie widzą jego spełnienie w śmierci i zmartwychwstaniu Jezusa (por. 1 Kor 11,25; Hbr 9,1115). Tak więc intencja modlitwy może wydawać się dwuznaczna. Zauważmy jednak, że takie właśnie jej sformułowanie pozwala na konsekwentne zacho-

${ }^{41}$ Por. H. Bi e te n h a d, Nome (onoma), [w:] Dizionario..., s. 1092-1098. 
wanie perspektywy pozwalającej ogarnąć jedną modlitwą wszystkich Żydów, cały lud wcześniej nabyty, a w konsekwencji, gdy chodzi o zasadniczą treść próśb, także całe potomstwo Abrahamowe, to jest całą oliwkę Izraela wraz $\mathrm{z}$ wszczepionymi przez Jezusa Chrystusa (= Mesjasza) dzikimi gałązkami narodów (por. Rz 11,16-18). Modlitwa bowiem, która pamięta o całym Izraelu, o jego dramatycznym rozdarciu spowodowanym przez Słowo żywe i skuteczne i ostrzejsze niż miecz (Hbr 4,12; por. Iz 55,10-11; Łk 12,51), a jednocześnie o całym Kościele Chrystusowym jednoczącym w Jego Ciele powołanych najpierw spośród synów Izraela a potem spośród wszystkich narodów musi odwoływać się do pojęć analogicznych, wyrastających ze wspólnego dziedzictwa a przez to samo „ekumenicznych”, lecz i otwartych na różną interpretację.

Potwierdzeniem zaś tego, że modlitwa chce rzeczywiście objąć tak szeroką pamięcią cały Izrael jest jej miejsce w odnowionym ciągu wezwań wielkopiątkowej modlitwy powszechnej. Nie było tu miejsca, by śledzić przeobrażenia całego tego kontekstu; zauważmy tylko, że ostatecznie w Mszale Pawła VI modlitwa Pro Iudaeis jest szóstą w ciągu dziesięciu modlitw, następując po modlitwach: Pro sancta Ecclesia, Pro papa, Pro omnibus ordinibus gradibusque fidelium, Pro catechumenis, Pro unitate christianorum, a przed modlitwami: Pro iis qui in Christum non credunt, Pro iis qui in Deum non credunt, Pro rempublicam moderantibus i Pro tribulatis ${ }^{42}$. Modlitwy poprzedzające są wszystkie modlitwami dotyczącymi Kościoła, szeroko w duchu Vaticanum II pojętego Ludu Bożego. Ostatnia z nich ogarnia „wszystkich braci wierzących w Chrystusa” i „uświęconych przez chrzest” - zarówno katolików jak i chrześcijan z innych Kościołów i wspólnot. Modlitwa za tych, którzy nie wierzą w Chrystusa, następuje dopiero po modlitwie za Żydów. Ta ostatnia wiąże się więc raczej z pierwszą grupą, w której wszystkie wezwania sformułowane są pozytywnie, poprzez to, czym są ci, za których się modlimy, a nie poprzez pewien brak, jak w dwu następnych prośbach; nie zakłada więc braku wiary w Chrystusa.

\section{Przektad polski}

Szkoda, że część bogactwa tekstów i podtekstów, którymi modlitwa za Żydów zwraca się do Boga nie została precyzyjnie oddana w oficjalnym polskim przekładzie tej modlitwy. Przypomnijmy tutaj, że pierwotna wersja tekstu nie doczekała się nigdy przekładu oficjalnego, gdyż radykalne jego zmiany zaczęły się przed wprowadzeniem języków narodowych do liturgii ${ }^{43}$. Mszał rzymski

42 Por. Missale Romanum... Editio typica altera 1975, s. 251-256.

43 Mszat Rzymski $z$ dodaniem nabożeństw nieszpornych w opracowaniu G. Le f e bv re'a OSB, w przekladzie poprawionym przez S. Swietlickiego i H. Nowackiego (Lophem-lez-Bruges 1931) daje przekład: „Módlmy się też i za wiarołomnych Żydów: niech Pan i Bóg nasz zedrze zasłonę z serc ich, aby z nami poznali Pana naszego Jezusa Chrystusa. (Nie odpowiada się Amen, a celebrujący śpiewa zaraz dalej:) Wszechmogący, wieczny Boże, który w miłosierdziu swojem niko- 
tacińsko-polski z r. 1968 zawiera wersję z Variationes z 1965 r. w następującym przekładzie ${ }^{44}$ :

Módlmy się także za Żydów:

niech Bóg i Pan nasz raczy ukazać im swoje jaśniejące oblicze, aby $i$ oni uznali Odkupiciela wszystkich ludzi Jezusa Chrystusa Pana naszego. Módlmy się. Klęknijmy. Powstańmy.

Wszechmogacy, wieczny Boże,

Ty dateś swoje obietnice Abrahamowi i jego potomkom;

wystuchaj łaskawie próśb swojego Kościoła,

aby lud, który niegdyś byt narodem wybranym,

mógł osiągną́ petnię odkupienia.

Przez Pana naszego.

Mszat rzymski dla diecezji polskich z 1986 r., będący tłumaczeniem Missale Romanum Pawła VI, daje następujący przekład nowego wezwania ${ }^{45}$ :

Módlmy się za Żydów, do których przodków Pan Bóg przemawiat, aby pomógt im wzrastać w miłości ku Niemu $i$ w wierności Jego przemierzu.

Przekład samej oracji został przeniesiony bez zmian z mszału z r. $1968^{46}$. $\mathrm{Na}$ pewno przekład i wydanie ksiąg liturgicznych w języku polskim jest wielkim i trudnym przedsięwzięciem i nie sposób zapewne w pierwszym wydaniu zwrócić uwagi na wszystkie niuanse znaczenia tekstu mogące ulec zniekształceniu przy tłumaczeniu — tak, że nie będzie niczym dziwnym, jeśli w niejednym jeszcze punkcie dociekliwi teologowie zgłoszą swe zastrzeżenia do przekładu. W każdym razie w interesującym nas przypadku oddanie zwrotu „populus acquisitionis antiquae” poprawionego później na „populus acquisitionis prioris” przez „lud, który niegdyś był narodem wybranym” jest dość swobodne, gubi chyba znaczną część teologicznej treści pojęcia acquisitio a po-

mu, nawet wiarołomnym Żydom, przebaczenia nie odmawiasz, wysłuchaj modlitw naszych za lud ten zaślepiony, aby wreszcie poznał światło prawdy, którem jest Chrystus i z ciemności został wybawion. Przez tegoż Pana... R. Amen." (s. 824). We wspomnianym wyżej wydaniu polskim z r. 1935 dzieła P. Guérange ra: Rok Liturgiczny, ci sami tlumacze tak modyfikują przekład: „Módlmy się i za wiarołomnych Żydów: aby nasz Bóg i Pan zedrzeć raczył zasłonę z ich serc, aby i oni poznali Jezusa Chrystusa naszego Pana. [...] Wszechmogący, wieczny Boże, który nawet i przewrotnych Żydów nie odtrącasz od miłosierdzia Twego: wysłuchaj modlitw naszych za ten lud zaślepiony, aby poznał Twojej prawdy światłość, którą jest Chrystus i z ciemności został wybawiony. Przez tegoż Pana... Amen" (s. 529-530).

${ }^{44}$ Mszat rzymski łacińsko-polski, Paryż 1968, s. 212. Podział na wiersze pochodzi od autora artykułu. Mszatu.

${ }^{45}$ Mszat rzymski dla diecezji polskich, Poznań 1986, s. 137. Podział na wiersze według tegoż

${ }^{46}$ Usunięto tylko, jak przy wszystkich modlitwach tej serii, wezwanie do uklęknięcia i powstania oraz zmieniono zakończenie na proste: „Przez Chrystusa Pana naszego”. Por. tamże, s. 138. 
nadto stwarza sugestię, jakoby lud, o który chodzi, utracił swoje wybraństwo, czego w żadnym wypadku nie sugeruje oryginał i co byłoby trudne do pogodzenia z wyraźną nauką Nowego Testamentu (por. Rz 11,1-2.11). Użycie liczby mnogiej: „Abrahamowi i jego potomkom” gubi chrystologiczny podtekst i w ogóle związek tekstu z Ga 3,16 utrudniając odkrycie, że motyw ufności jest wspólny dla proszącego Kościoła i ludu, za który się prosi. Określenie Żydów, za których mamy się modlić, jako tych, „do których przodków Pan Bóg przemawiał" osłabia świadomość historycznej jedności całego ludu wyraźną w łacińskim sformułowaniu ,ad quos prius locutus est Dominus Deus noster”. Oddanie oryginalnego „tribuat ... proficere” przez „(aby) pomóg1 [...] wzrastać” chyba nie dość oddaje całkowitą zależność owego wzrostu od daru Bożej laski. Może dałoby się wziąć pod rozwagę na przyszłość tych kilka uwag, zważywszy, że nowy Mszat nie przewiduje już paralelnego tekstu lacińskiego dającego możność bezpośredniej kontroli oryginalnego sensu oficjalnej modlitwy Kościo$1 a^{47}$.

Próbowaliśmy prześledzić na kilkunastu poprzednich stronicach dzieje sformułowania jednej z szeregu orationum solemnium Wielkiego Piątku i wejrzeć w wewnętrzną logikę dokonywanych przemian oraz ich teologiczną wymowę. Zauważyliśmy, jak odważne skreślenie przez papieża Jana XXIII jednego pejoratywnie brzmiącego określenia doprowadziło do przebudowy calego tekstu uświadamiającej złożoność (i bogactwo) wzajemnej relacji Izraela i Kościoła. Usunięcie precyzacji perfidi doprowadziło w konsekwencji do takiego ustawienia modlitwy, przy którym widać, iż nie można całości stosunku Kościoła Chrystusowego do Żydów ująć w postaci stosunku zewnętrznego dwu odrębnych, rozłącznych podmiotów (Ecclesia - Synagoga), lecz trzeba stale mieć na oku dramat rozdarcia organicznej (w nadprzyrodzonym sensie) całości mającej wspólny korzeń, wspólne dziedzictwo i wciąż żywą, nieredukowalną część wspólną istotną dla pełnego określenia tak Izraela jak i Kościoła.

Jednocześnie można chyba powiedzieć, że o kierunku przemian modlitwy za Żydów zadecydowało ogólne nastawienie Soboru: bardziej pastoralne niż dogmatyczne. Przebudowa modlitwy rozwiązuje bardzo ważny pastoralnie problem wychowania wiernych przez modlitwę do szacunku, miłości, poczucia

47 Nie chcąc kończyć samym biadaniem, przedstawiam taką propozycję przekladu: „módlmy się i za Żydów, aby Pan Bóg nasz tym, do których wcześniej przemówil, dal wzrastać w miłości swego imienia i w wierności swemu przymierzu. Wszechmogący, wieczny Boże, Ty dałeś swoje obietnice Abrahamowi i jego potomstwu. Wysłuchaj łaskawie próśb swojego Kościoła, aby lud wcześniej nabyty mógł dojść do pełni odkupienia. Przez Chrystusa Pana naszego. Amen.”. 
solidarności z narodem żydowskim. Stara się wykluczyć możliwość wynoszenia się, pogardy, antysemityzmu. Odwołując się wszakże do wspólnych początków, do Bożych obietnic, do tego, co nas łączy, nie ujawnia, ukrywa w głębiach analogii biblijnych to, co dzieli, głęboki ból, który należy nieodłącznie do tajemnicy Kościoła, dokąd nie runie do końca „rozdzielający mur” przezwyciężony już w męce Głowy (por. Ef 2,14). Ukrycie bólu może być wyrazem dojrzałości, jeśli wynika z miłości, która rozumie i świadomie akceptuje zarówno sam ból i jego źródła jak i motywy powściągliwości i dyskrecji. Wydaje się, że obecna formuła modlitwy za Żydów zakłada u chrześcijan, domaga się od nich większej dojrzałości w wierze, głębszej świadomości jej tajemnic, w szczególności znajomości całej nauki św. Pawła o misterium Izraela. Źle by się stało, gdyby odnowiona i pogłębiona katecheza Kościoła nie uświadamiała wyraźnie tej nauki wierzącym, gdyby, w związku z tym (wbrew swym najgłębszym intencjom) odnowiona modlitwa liturgiczna miała działać jak środek znieczulający, pozwalający zapomnieć o istniejącym rozdarciu, o głębi miłości, wiary, nadziei, modlitwy potrzebnych dla doprowadzenia do pełni Odkupienia całego Izraela Bożego.

\section{IL SENSO DELLE TRASFORMAZIONI DELLA PREGHIERA PER GLI EBREI NELLA LITURGIA ROMANA DEL VENERDI SANTO}

\section{Riassunto}

Il fatto del togliere via le espressioni perfidi e perfidia dal testo delle solenni preghiere del Venerdì Santo (avvenuto nel 1959 per la decisione del papa Giovanni XXIII) ha aperto la strada per i successivi cambiamenti che, alla fine, hanno portato ad un testo del tutto nuovo della preghiera per gli Ebrei. Dato che il modo di concepire l'identitá degli Ebrei e il modo di pregare per essi sono interdipendenti, sembrava interesante di studiare, da questo punto di vista, le successive formule liturgiche.

L'analisi teologica del testo antico, di quello „epurato” da Giovanni XXIII, del testo parzialmente cambiato nel 1965 e di quello del Messale di Paolo VI ha mostrato un passaggio dalla preghiera riguardante quella parte d'Israele che non ha accettato Gesù come Messia e legata proprio al fatto di quel indurimento di cuore la cui cessazione si chiede a Dio, ad una preghiera per intero popolo eletto visto dalle sue radici, una preghiera dove si chiede i beni supremi ruguardanti sia gli Ebrei che la Chiesa stessa. Si nota il carattere „ecumenico” e educativo della formulazione nuova senza tacere il fatto che essa è meno esplicita quanto alle verità dogmatiche riguardanti il mistero d'Israele, specie quel indurimento di cui parla San Paolo (cf. 2 Cor 3,12-16; Rom 9-11). Si fanno anche alcuni osservazioni riguardanti la traduzione ufficiale polacca del testo della preghiera e si propone di raffinarne alcune espressioni. 